\title{
Higher Education Marketing Communications in the Digital Era
}

\author{
By Mark Anthony Camilleri ${ }^{1}$, University of Malta, Malta AND University of Edinburgh, UK.
}

This is a prepublication version.

How to Cite:_Camilleri, M.A. (2020). Higher Education Marketing Communications in the Digital Era. In Mogaji, E.O., Maringe, F. \& Hinson, R.E., Marketing Higher Education in Africa: Challenges and Opportunities. 1st Edition, CRC Press (Routledge), Oxford, UK. https://www.crcpress.com/Strategic-Marketing-of-HigherEducation-in-Africa/Mogaji-Maringe-Hinson/p/book/9780367336356.

\begin{abstract}
This chapter examines the global marketing environment of today's higher education institutions (HEIs). (Semi) Autonomous HEIs and business schools are increasingly behaving like for-profit organisations as they seek new opportunities and resources to prioritise revenue creation. Therefore, they are diversifying the portfolio of their student populations by recruiting domestic and international students. In this light, this contribution deliberates on contemporary integrated marketing communications that are intended to support HEIs to promote their quality, student-centred education as well as their high-impact and meaningful research in global markets. Moreover, it reports on how HEIs' marketing endeavours will be able to forge fruitful and collaborative relationships with industry stakeholders; foster student mobility and engagement in exchange programmes, as they can create partnership agreements with other institutions, among other strategic avenues. These issues imply that tomorrow's educational institutions will have to keep investing in adequate resources, competences and capabilities to leverage themselves amid intensifying competition in challenging socio-economic environments.
\end{abstract}

Keywords: Marketing Communications; Higher Education; Higher Education Marketing; Higher Education Institutions; Stakeholders; University.

\footnotetext{
${ }^{1}$ Department of Corporate Communication, Faculty of Media and Knowledge Science, University of Malta, Malta AND The Business School, University of Edinburgh, UK.
} 


\section{Introduction}

Higher education institutions (HEIs) are influenced by political and socio-economic changes in their marketing environment (Beine, Noël \& Ragot, 2014; Constantinides \& Zinck Stagno, 2011; Maringe \& Gibbs, 2008; Hemsley-Brown \& Oplatka, 2006; Mazzarol \& Soutar, 2002; Mazzarol, 1998). Currently, HEIs hailing from the advanced economies are affected by adverse demographic trends. Many developing countries have an ageing population and are experiencing lower birth rates. The annual growth in outbound student numbers is expected to decline from 6\% to $1.7 \%$ per year till 2027 (British Council, 2018). At the same time, Universities and other educational institutions are facing intensifying competition, as they operate in a global marketing environment (Schofield, Cotton, Gresty, Kneale \& Winter, 2013). Therefore, HEIs and business schools hailing from developed and developing countries have to formulate policies and strategic objectives that will allow them to evolve (Pucciarelli \& Kaplan, 2016; Ivy, 2008; Kotler \& Fox, 1995). HEIs may have to diversify their student populations by expanding the recruitment of international students in their home campuses (Lee, 2014), and/or by serving new markets, with satellite campuses (Pucciarelli \& Kaplan, 2016; Friga, Bettis \& Sullivan, 2003). Thus, internationalisation has become an institutional imperative, for many HEIs (Schofield et al., 2013), as they are increasing offering courses in different settings.

(Semi) Autonomous HEIs are behaving like for-profit organisations as they often seek new opportunities and resources from developing countries in the Middle East, Africa and South East Asia, among other regions to prioritise revenue creation (Pucciarelli \& Kaplan, 2016; Budde-Sung, 2011; Altbach, Reisberg \& Rumbley, 2009). Hence, they internationalise; in terms of faculty, students, and curriculum. Institutions target international students because they pay higher tuition fees than their domestic counterparts (Altbach, 2004; Lee, 2014). 
Moreover, institutions are introducing alternate modes of delivery of education, as they offer distance and online learning (British Council, 2018; Camilleri \& Camilleri, 2019; Schofield et al., 2013). Therefore, universities and business schools are increasingly promoting their higher educational services in global markets (Pucciarelli \& Kaplan, 2016; De Jager \& Gbadamosi, 2010; Friga et al., 2003).

In this light, this contribution uses a generic approach to assess the internal strengths and weaknesses of today's higher education institutions, including universities and colleges. The researcher critically analyses the opportunities and threats of their macro marketing environment. After having reviewed the current situation, he presents contemporary marketing communications tactics that may be used by the HEI leaders to promote their services. In a nutshell, this chapter explains how educational institutions can make use of traditional and digital media to attract students as well as academic members of staff.

\section{Literature Review}

HEIs, including those operating from the African continent, are facing intensifying competition, as they operate in an international marketing environment (Maringe \& Gibbs, 2008). At the same time, they are encouraged to recruit larger, international student intakes as they face financial constraints to survive in a competitive marketplace (Russell, 2005). As a result, universities may diversify their student populations by expanding the recruitment of international students for their home campuses (Lee, 2014), and / or by serving new markets, by entering foreign countries with satellite campuses (Pucciarelli \& Kaplan, 2016; Friga et al., 2003). Hence, universities need to adopt a consumerist approach whilst taking into account the environmental factors (Pucciarelli \& Kaplan, 2016; Friga et al., 2003). 
Relevant academic literature suggests that the HEIs' performance is shaped by many entities at both supranational and national levels (Estermann, Nokkala \& Steinel, 2011; Maton, 2005). Estermann (2017) contended that the universities' political autonomy and academic freedom is a fundamental pre-requisite for them, to be able to develop their strategic profiles. The European University Association has called on the national governments to refrain from interfering with the universities' autonomy and accountability (EUA, 2017). The public authorities may also exert their political influence through their funding mechanisms, and concentration processes, that can have an effect on their management. Altbach (2004) argued that institutions ought to design fundraising activities that target companies and alumni. The author contended that HEIs could promote their continuous professional development opportunities as they can deliver courses to executives. Notwithstanding, the challenging economic context can also have an impact on the HEI's financial management, staffing matters and organisational aspects (Estermann, 2017). The universities increased autonomy, selforganisation, and accountability (Hoecht, 2006) has brought some level of privatisation of the higher education sector and has facilitated the entrance of new players (Pucciarelli \& Kaplan, 2016).

The university leaders are not always market-oriented and their institutions may not always be capable of differentiating themselves by marketing their high quality "product" (Pucciarelli \& Kaplan, 2016; Ivy, 2008). Russell (2005) argued that the classrooms' resources and the effective management of physical assets are also important determinant for the students' perceptions on higher education and service quality. This author made reference to specific aspects such as the HEIs' campuses, their infrastructure and surroundings, as well as other evidence that may influence customer perceptions, including; their prospectuses, web sites, exhibition stands, stationery and business cards. These are important elements to prospective 
students, particularly for those who are not be able to visit the campus prior to committing themselves to enrol in a specific HEI.

Kotler and Fox (1995) argued that the general public may usually form images of HEIs that could affect the likelihood of students attending or recommending institutions to others. In a similar vein, Paramewaran and Glowacka (1995) held that higher educational institutions need to maintain or develop a distinct image to create a competitive advantage. HEIs need to maintain or develop their corporate image as they want to occupy a position in the minds of their students. Mazzarol's (1998) research reported that the institutions in Australia, Canada, New Zealand, the UK and US enjoyed a good image and reputation in terms of fostering a culture of innovation, while Bharadwaj, Varadarajan and Fahy (1993) had emphasised the importance of organisational learning and expertise as a source of competitive advantage. These studies suggested that students' decisions when selecting courses were based on the reputation and experience of the universities' faculty staff (Mogaji, 2016; Beneke, 2011; Van Heerden, Wiese, North \& Jordaan, 2009). The university's service quality relies on "human actors" who are entrusted to deliver individualised, student-centred experiences (De Jager \& Gbadamosi, 2010).

The universities' classes may be composed of diverse students hailing from different cultures, beliefs and geographical backgrounds. This issue has led to drastic shifts in the students' expectations regarding their classroom experience (Budde-Sung, 2011; Altbach et al., 2009; Friga et al., 2003). The international students may usually value the educational institutions' quality and reputation as well as the recognition of their qualifications in their own country (Beneke, 2011; Van Heerden et al., 2009; Binsardi and Ekwulugo, 2003; Mazzarol \& Soutar, 2002). Kotler and Fox (1995) posited that the university's perceived excellence has usually affected the decisions of prospective students and scholars to choose one HEI over another. 
The authors contended that the HEIs' main focus of attention should be on increasing their service quality whilst delivering "perceived excellence". Customer satisfaction correlates with perceived quality (or, attitude towards HEIs' products), which ultimately affects their profitability (Duque, 2014; De Jager \& Gbadamosi, 2010; Mazzarol \& Soutar, 2002; Cronin \& Taylor, 1992). For this reason, the HEIs need to enhance their prestige (Pucciarelli \& Kaplan, 2016). If they do so, international students may be willing to pay higher "prices". In a similar vein, Binsardi and Ekwulugo (2003) held that the product and pricing variables ought to be considered when HEIs formulate their market penetration strategies, Eventually, Pucciarelli and Kaplan (2016) went on to suggest that HEIs need to expand interactions with key stakeholders whilst co-creating value with them. Like other for-profit businesses, HEIs ought to nurture relationships with a range of stakeholders, including; students and their parents, policy makers, employers as well as with other universities and colleges (Maringe \& Foskett, 2002).

Previous literature reported that the best way to attract international students is to lower tuition fees; provide more scholarships, and better service quality to students (Binsardi \& Ekwulugo, 2003; Mazzarol \& Soutar, 2002). HEIs may also benefit of education marketing (Constantinides \& Zinck Stagno, 2011; Maringe \& Gibbs, 2008; Hemsley-Brown \& Oplatka, 2006; Mazzarol, 1998) and promotions, including; word of mouth publicity on positive learning experiences from students themselves, and from their friends and relatives. Furthermore, HEIs may resort to integrated marketing communications as they may use broadcast, digital and outdoor advertising, sales promotions, personal selling, direct marketing, interactive marketing, public relations and publicity, to raise awareness of their educational services (Maringe \& Foskett, 2002). The advances in technology can provide significant opportunities for HEIs to leverage themselves through online media (Pucciarelli \& Kaplan, 2016; Njenga, \& Fourie, 2010). HEIs may be in a position to address the increasing demand 
for distance learning education that cannot be fully met through offline channels Schofield et al., 2013). The use of digital media can also result in significant cost savings, as the transition from physical to digital solutions improves efficiency and effectiveness (Moore \& Kearsley, 2011). Notwithstanding, today's students are becoming very acquainted with the use of ubiquitous technologies in the realms of education (Camilleri \& Camilleri, 2017, 2019; Njenga, \& Fourie, 2010). Therefore, it is in the interest of HEIs to keep up to date with the latest developments in the marketing environment.

\section{A Critical Analysis of the HEIs' Marketing Environment}

The researcher has outlined a non-exhaustive list of the HEIs' strengths and weaknesses. It also shed light on possible opportunities and threats from political, regulatory, socio-economic and technological issues (Helms \& Nixon, 2010; Marginson, 2006).

\section{A SWOT Analysis on the HEIs' Strategic Orientations}

\section{Strengths}

- HEIs raise their financial capital requirements by charging tuition fees to full time, part time and distance learning students; Government-funded HEIs may provide free or reduced tuition fees;

- Many international courses are taught in English; The English language has become an important lever for international student mobility (ICEF, 2017);

- Several HEIs provide work-integrated education; they deliver pragmatic, applicationoriented programmes. The students are/may be expected to undertake industry placements 
as part of their studies. Therefore work-integrated education (WIE) may be a component of the HEIs' curriculum.

- Work-integrated education supports students to become all-round professionals with an appropriate level of operational experience. It equips students with a thorough understanding of the business and industry's operations. WIE would usually take place in an organisational context that is relevant to the students' future employment prospects. At the same time, the students would obtain communicative and transferable skills that will be valuable for their development. The focus is to help them acquire a range of valuable generic abilities, including people-skills through interactions with peers, subordinates and supervisors. After their working period, the students will be in a position to apply the theories that they have learnt in real-life settings. Hence, students develop their knowledge and skills in a professional environment, whilst increasing the chances of their employability prospects (Kolb \& Kolb, 2005);

- HEIs are increasingly establishing international collaboration agreements with other educational institutions, across borders. They enable student exchange programmes and field trips. The classroom teaching is enriched with student exchanges and field trips that provide students relevant on-the-job training;

- HEIs are building their alumni networks over the years. Many of their students have become business and industry professionals.

- HEIs are often engaging with business and industry as they provide their consultancy and research services;

- HEIs offer Executive Development Programmes to industry practitioners, allowing them to update their skills, and to broaden their knowledge.

\section{Weaknesses}

- Many HEIs are not managed as profitable organisations;

- HEIs' academic employees may become members in trade unions. The unions can use their bargaining power on the university's administration;

- HEIs can be slow to respond to the ongoing changes in the business and industry. They may need to adapt their curricula and courses to better meet the prospective employers' requirements; 
- The HEIs' academic members of staff may have long contact hours with their students (when compared to other institutions);

- The HEIs' academia are not always publishing adequate and sufficient research (when compared to other institutions);

- The HEIs' prospective students may be attracted to competitive institutions who are offering cheaper tuition fees. The international prospects will consider the HEIs' locations and their living expenses;

- The HEIs' international marketing efforts may be focusing on limited catchment areas. They may be overlooking promising markets (Constantinides \& Zinck Stagno, 2011).

\section{Opportunities}

- HEIs may use educational technology to improve their students' experience. Educational technologies could enhance the quality of online courses, particularly those that are offered to part-time, or distance learning students;

- HEIs can utilise blogs, RSS feeds, podcasts, wikis, electronic fora, webinars, et cetera to reach their target audiences. They may use social media and word of mouth marketing by communicating student testimonials, online reviews and ratings, in order to attract students from different markets;

- HEIs could incentivise their educators and researchers to participate in academic conferences and to publish their work in highly indexed journals;

- The setting up of research (or special interest) groups could improve collaboration and teamwork among the HEIs' members of staff;

- HEIs' academics should be encouraged to become members in editorial boards of leading journals;

- HEIs can offer high-level consultancy and professional advisory services to private and public organisations;

- HEIs may organise international conferences and fora that can be used as a platform for insightful exchange amongst academics, industry practitioners and tourism policymakers;

- HEIs can engage with alumni by involving them in social events, webinars and continuous professional development programmes;

- Industry professionals can be invited to speak to students on specific subject lectures. These experts may help students gain a deeper understanding of the industry; 
- HEIs' academia should be encouraged to share their research expertise with business and industry to pioneer developments. They should promote their research outputs (Duque, 2014; Parameswaran \& Glowacka, 1995). Relevant research can enhance industry performance and influence policy making;

- HEIs can extend collaborative agreements in many areas, with reputable education institutions;

- HEIs can obtain quality assurance and accreditations from international awarding bodies, for their educational programmes. The recognition of their courses would necessitate a thorough assessment of their leadership, curriculum programmes and skills, assessment methods, project work, student placements, student support, feedback and resources, et cetera;

- The HEIs' international admissions pages should evidence their 'global perspective' and could highlight their extensive range of services they offer to international students. For example, their course prospectus should be available in different languages;

- There is an increased demand for higher education from mature students as the concept of life-long learning is being promoted in developing and advanced economies;

- There are still untapped markets in Asia where students can't access quality education at home. There is a business case to attract students from Africa as the continent's youth population is rising (British Council, 2018; Camilleri, 2016a,b);

- The HEIs' international students could be used as brand ambassadors and should be featured in their digital media;

- HEIs may be supported by student scholarships (from governments, foundations or NGOs) and sponsorships that may be donated by industry partners.

\section{Threats}

- Many HEIs' national governments have already decreased (or cut) their public funding to HEIs (Estermann, 2017; Estermann, Nokkala \& Steinel, 2011; Hoecht, 2006; Maton, 2005). Therefore, HEIs may have to raise their capital requirements through tuition fees and fund-raising activities;

- There is a very competitive environment (in the global market). HEIs are increasingly targeting international students from many markets; 
- Many countries (including developing economies) have improved (or are improving) their educational systems. However, there may be students who decide to go abroad because they believe that there is neither capacity nor high-quality education at their home country (ICEF, 2017);

- The aging populations in many parts of the world, their greater life expectancies, coupled with lower fertility rates, means that populations in many countries are getting older. At the same time, the 15-to-24-year-old cohorts are shrinking. This key college-aged demographic will peak in Asia somewhere around 2020. Then it will start a gradual decline from that high point (British Council, 2018);

- There may be political, socio-cultural and legal factors affecting the marketing of HEIs. International students may face travel restrictions. Rigorous travel formalities including the issuance of national visas and immigration policies, can affect the students' choice of their prospective HEI;

- Reduced scholarships and student exchange programmes from foreign governments can have an impact on the number of students who may afford international mobility;

- A growing number of Asian students are choosing to stay within their own region to study, and students from other countries - including African nations- are adding Asian destinations to their list of attractive options. Asian countries, including China, Japan, South Korea, Singapore and Malaysia, among others, are increasing their capacity to absorb international students. Students and families are placing more emphasis on value, and on the return on investment from overseas education. Therefore, students may opt to study close to their home;

- There are growing indications that major employers are placing less emphasis on reputable HEIs and their brand identities (ICEF, 2017).

\section{The HEIs' Integrated Marketing Communications}

The integrated marketing communications campaigns of HEIs ought to be based on clear strategies that will help them achieve their goals and objectives. There are different promotional tools that are distinct from each other, in terms of their purpose. Therefore, the 
HEIs' marketing managers need to coordinate their various promotional activities into a concerted and organised manner. They have to allocate adequate financial resources in support of every marketing activity, so that all touch points will convey consistent messages to the desired target audience (Bonnema \& Van der Waldt, 2008). Hence, HEIs ought to consider their (i) market, (ii) mission, (iii) message, (iv) media, (v) money and (vi) measurement, whenever they use their marketing communications tools:

\section{The Market}

The market includes both competitors as well as customers. The competitors are other HEIs who are targeting prospective students. The customers include domestic and international college students, as well as employees who pursue life-long learning opportunities and continuous professional training and development.

\section{The Mission}

The marketing objectives may include increased sales volumes, market share, return on investment, and profitability. The communication objectives may include; raising awareness of a product or service, increasing the consumer knowledge of the product features and attributes, improving the consumers' preferences and convictions toward the product, and entice customers to make their purchase decisions, among others (Ivy, 2008). The latter objectives are related to the hierarchy of effects model, which map out the response process of prospective customers before their actual purchase. One premise of this process is that the marketing communications take time to yield results. Another aspect of this model is that; different elements of IMC can be very effective and specifically targeted at integral steps in the response process. For example, advertising is an excellent tool to raise awareness and to convey information on a product or service. Public relations may be used to generate interest 
and desire. Personal selling through open-day events (which would necessitate face-to-face interactions) may be used to convert preference and conviction into purchase behaviours.

\section{The Message}

The HEIs ought to adapt their promotional content to different markets. Educational institutions would better use the local language of their prospective students. They should consider their prospects' socio-cultural norms, beliefs and expectations before formulating their marketing messages. Hence, HEIs may decide to test their promotional content with various groups of students in order to ensure that their message is clear and effective for the target market, before launching their marketing campaigns (Bonnema \& Van der Waldt, 2008). Afterwards, HEIs may be in a position to communicate their strategic messages that promote the specific aspects of their quality educational services, for example; (i) their student-centred teaching culture; (ii) the provision of work-integrated education for full time students, as part of their academic work; (iii) ambitious objectives that are intended to attract the best employees and to retain them; (iv) nurturing human resources, through ongoing training opportunities and continuous professional development; (v) significant investments in appropriate cost-effective enhancements to the extant infrastructure in support of research, scholarship, and creativity; (vi) incentive research output and improve its impact, particularly in the fields of critical importance, for societal benefit; (vii) forging collaborative relationships with other HEIs to enhance the quality and stature of academic disciplines or fields; (ix) engagement with stakeholders, including the government and its policy makers, as well as with business and industry; (x) encouraging undergraduate students to pursue post-graduate studies; implementing strategically-focused; (xi) fostering a diverse workplace, student body, and staff in terms of gender, race and ethnicity; (xii) recruiting new PhDs and "rising stars". 


\section{The Media}

The marketers who possess a generous budget may have access to an arsenal of communication options, including electronic media (TV and radio), print media (newspapers and magazines), direct-mail solicitations, telemarketing, personal selling, public relations and the web, among others. One medium is seldom enough to reach segments. The choice of media depends on a number of factors, including: (i) the markets which are being targeted; (ii) the combination of media which will be the most effective to the target markets; (iii) the amount of money that is dedicated to the marketing communications budget, which can be affected by the decisions made in (i) and (ii).

\section{Advertising}

HEIs can advertise in print media in different countries. Newspapers and magazines can report news releases that promote the HEIs' credentials, in terms of quality educational programmes, high impact research, as they may provide relevant information on the institutions' engagement with stakeholders, including business and industry. Moreover, digital advertising can deliver effective results for the marketing of HEIs, for far less of an investment. For example, the PayPer-Click (PPC) advertising is often used to target potential markets, as the sponsor only incurs an expense when prospects click on the online banner. However, before launching the PPC campaigns and their related analytics, the HEIs should improve their landing pages to specific sites that would appeal to online prospects; who are seeking information on particular degrees and academic programmes. 


\section{Direct Marketing via Digital and Mobile Technologies}

The HEIs' website should be accessible through different devices; via desktop computers, smart phones, tablets, et cetera. The online content should be optimised for mobile-device usage as many international students are mobile-exclusive. Hence, HEIs should communicate relevant details of their selling propositions, in different languages. They can provide information on course admissions; collaborative agreements with stakeholders; student mobility; research opportunities; et cetera. International students will also require factual data, on tuition and bench fees, as well as on study and work permits, among other issues.

The HEIs' web sites could offer personalised, interaction facilities in real time, through live chat services. They can use web-conferencing via easily accessible tools like Skype or Google Hangouts to engage with prospective students in their queries, or to address their concerns, share documents or videos, and guide them through relevant webpages, via co-browsing. HEIs can organise webinars for parents and prospective students, with admissions and faculty employees in multiple languages. Moreover, the HEIs' website could feature student testimonials, including; reviews and ratings that may serve as proof that they are providing an adequate level of service to their scholars. The positive experiences from the students themselves, will help them attract new ones.

The HEIs' web sites should be structured and well-deigned with a good selection of high resimages, video, et cetera. They may also incorporate the Google Maps Street View or Oculus Rift virtual reality technology as they allow prospects to visualise the premises of their prospective campus. Attractive websites could entice visitors to fill their subscriber list to receive electronic newsletters and promotional material, via email. This direct marketing tactic enables HEIs to communicate directly with prospective students through a variety of media, including; by electronic newsletters, mobile messaging apps, websites, online and offline 
catalogues, promotional letters, among others. The HEIs' direct marketing seeks to create oneto-one personal relationships with prospective students. Its underlying goal is to generate a response from the prospects themselves.

In this day and age, the engine behind direct marketing is usually a sophisticated database. The collection of data is growing at an exponential rate as it is continuously stored, in massive amounts, by search engines, including; Google and Bing, among others. The advances in technology are increasingly allowing marketers to know more about their audiences. For instance, marketers are benefiting from the growth of geo-location data services like satellites, near-field communication and global positioning systems that track the users' movements that measure traffic and other real-time phenomena. New anonymous cookie-less data-capture methods are connecting the consumers' data with geolocation-based data. These methods are increasingly empowering marketers as they use Google's and Bing's Business Solutions, to hyper-target online users with real-time mobile ad campaigns to drive conversions. For example, the HEIs' marketers can use Google AdWords to know about the most popular search terms, as they could identify which ads are converting prospects. AdWords identifies the combinations of keywords and messages that are the most effective in particular markets. In addition, Google Analytics enables the HEIs to have an accurate picture of their web activity. As a result, they will be in a position to track and monitor their online marketing effectiveness, whilst segmenting and customising communications.

\section{User-Generated Content, Interactive Marketing and Social Media}

HEIs can also use external websites and online portals that feature user-generated content that promotes higher education courses, in different contexts. For example, Wikipedia pages can reach broad audiences, and they enjoy high credibility with search engines. 
Moreover, HEIs can engage with prospective students through conversations, informal surveys and informational posts that are intended to improve interactions with online users. Communications on social networks, including Facebook, Instagram, Snapchat, Twitter and Linkedin, among others can be used to filter unqualified prospects. These networks may reveal interesting insights on the prospects' language proficiencies, interests and on their perception of the HEIs' brand image (Beneke, 2011). Social media provides an opportunity to HEIs to improve their brand awareness. Therefore, they should establish their presence on social media platforms in different markets. HEIs are increasingly relying on the most popular social networks as interested prospects may be intrigued to share and spread promotional content, online. Such digital marketing stimuli may result in social contagion by means of e-mails, posts, likes, tweets, mentions, et cetera. This would lead to a viral dispersion of the HEIs' marketing messages as effective marketing campaigns may trigger a strong emotional response among prospects. Therefore, HEIs may leverage themselves through word-of-mouth (WOM) publicity on social networks. For instance, they could join WeChat and Sina Weibo to target Chinese prospects.

\section{Public Relations and Publicity}

The testimonials of students or alumni would probably reveal meaningful information on the quality of educational institutions or on the effectiveness of their curriculum programmes. These communications may be available in different languages in order to provide peer affirmations to a wide array of local and international students. The videos of the students' referrals that aren't scripted may appear as more authentic than professionally edited marketing material. Such word-of-mouth publicity may prove to be more credible and trust-inspiring than academic awards, accreditations, or past statistical information. HEIs may feature the success stories of their former alumni who are now engaged in key government or corporate positions. 
They may provide internship programmes to their former HEIs' students. At the same time, they may benefit from a talent pool of promising students.

HEIs can improve their brand equity by organising public relations activities on campus, including; summer camps, open day events, et cetera. They can attract international students from different markets to follow academic courses in specific disciplines.

\section{Personal Selling}

Inevitably, the positive or negative word-of-mouth publicity could affect the prospective students' perceptions of HEIs. Therefore, front office employees in the admissions department would be in an excellent position to engage in two-way communications with potential students. The HEI's admissions department must be aware that they are 'selling' the university when they provide their technical support to prospects, applicants and admitted students with their queries. They may also need to be proficient on how to handle complaints. Therefore, front office employees ought to be monitored and evaluated on a regular basis.

\section{The Money}

How much will be budgeted for each and every marketing tool? Many HEIs may rely on the budget allocation from their national government. Alternatively, they may be receiving some financial support from alumni, corporations, foundations, et cetera. Yet, HEIs should continuously seek new and diversified funding sources and methods. Their potential sources of income may include; tuition fees for courses, national and international research grants from institutional funding, as well as 'other' income sources that could be obtained from consultancy, conferences, specialised courses, knowledge exchange/technology transfer, et 
cetera (Njenga \& Fourie, 2010). They could engage in collaborative agreements with reputable research institutes to benefit from the pooling of institutional resources and expertise.

\section{The Measurement}

Very often, HEIs claim that their graduates are finding rewarding careers following the completion of their degrees. These statements need to be substantiated with evidence. As a matter of fact, the students' career outcomes are often considered as one of the most important factors that will influence student decision-making. This is particularly true for many disciplines and recruitment markets. Therefore, HEIs should regularly monitor their progress against their set priorities, commitments, and aims, by using relevant performance indicators, benchmarks, and targets.

HEIs should measure the performance and successes of their marketing strategies. Key metrics could analyse and measure; student enrollment ratios, graduate rates, student drop-out rates, the students' continuation of studies at the next academic level, the employability index of graduates. Other metrics may involve the calculation of their costs per credit, costs per degree and student-faculty ratio, among others.

HEIs may want to find out the students' opinions and perceptions toward their host institutions. This data can be used to identify the HEIs' strengths and identify other areas that may require further improvement. Qualitative research may shed light on the HEIs' progress on planned goals, objectives, and strategic initiatives. These insights could provide valuable data on the students' opinions and perceptions of their learning environments. Conversely, HEIs may explore the students' attitudes through quantitative research that will analyse courses (including undergraduate, graduate, and professional). Survey instruments could measure the students' satisfaction with teaching; research opportunities. They could reveal the students' attitudes on 
international and public engagement opportunities; ease of taking courses across boundaries and investigate whether there are any administrative/bureaucratic barriers at their respective HEI.

Other metrics may evaluate the HEIs' strategic priorities and initiatives; including ongoing assessments of academic and administrative staff, and their retention rates. They may track changes in faculty size; outline the age distribution of academic employees; diversity of students and staff, in terms of gender, race and ethnicity, et cetera. HEIs could examine discipline-specific rankings; and may involve a continuous scrutinisation of courses, research output, reviews of expenditures per academic member of staff, et cetera.

In addition, more and more institutions are keeping a track record of their alumni, although they may not always differentiate between the outcomes for domestic and international students. However, they will probably report on the cohort of students' career progression following the completion of their education. HEIs often mention specific companies that have employed their graduates. In addition, HEIs may gather data on the international students' attitudes toward housing and determine if they are happy in their new location.

HEIs may have a good reputation in specific regions or countries (Beneke, 2011). Nevertheless, international students will usually rely on the international rankings to quickly understand the quality of their potential host institution and its educational programmes. They may come across "league tables, such as the Academic Ranking of World Universities from Shanghai Jiao Tong rankings; Times Higher Education World University Rankings; "Professional ranking" of world universities from the École des Mines de Paris or QS rankings, among others. These rankings usually adopt a number of metrics and key performance indicators to differentiate among HEIs. 


\section{Conclusions and Implications}

In recent years, there were significant changes in the governance of HEI systems in developed as well as in developing countries. Many renowned universities and educational institutions have already introduced marketisation policies as they compete for domestic and international students. At the same time, the marketisation of higher education has become less dependent on state control and government intervention. In response to these challenges, HEIs are resorting to contemporary marketing strategies and tactics to garner a larger share of the international market (Mogaji, 2016). Many universities are increasingly crunching big data and analytics to tap into new market segments in different contexts; as well laid-out integrated marketing communications plans are providing the right pathways for growth.

This chapter's SWOT analysis has suggested that HEIs' long term sustainability is dependent on the recruitment of international students and faculty employees. Therefore, international HEIs operating in different markets, including those that are located in the African continent, should formulate strategic plans in order to increase their international student figures, enhance research collaborations, foster student mobility in exchange programmes, and forge partnership agreements with business and industry. HEIs ought to invest in resources, competences and capabilities to attract domestic and international students (and staff) to improve their financial and strategic performance.

Not all HEIs, colleges and business schools are responding to the political, socio-economic and technological changes in a timely manner. Arguably, those HEIs who are still benefiting of public funding, will not have an urgency to differentiate themselves from their competitors. However, autonomous institutions are in a better position to leverage themselves through effective marketing communications. This way, universities and colleges hailing from different contexts may be in a position to compete in a global market environment and to increase their 
brand equity among foreign students. Of course, the educational institutions need to ensure that their quality claims are substantiated, year after year.

\section{References}

Altbach,P.G. 2004. Globalisation and the university: Myths and realities in an unequal world. Tertiary Education and Management,10(1): 3-25.

Altbach, P. G., Reisberg, L., \& Rumbley, L. E. 2009. Trends in global higher education: Tracking an academic revolution. A Report for UNESCO World Conference of Higher Education.

http://www.cep.edu.rs/public/Altbach,_Reisberg,_Rumbley_Tracking_an_Academic_Revolut ion,_UNESCO_2009.pdf accessed 20 $0^{\text {th }}$ July, 2019.

Beine, M., Noël, R., \& Ragot, L. 2014. Determinants of the international mobility of students. Economics of Education review, 41: 40-54.

Beneke, J. H. 2011. Marketing the institution to prospective students-A review of brand (reputation) management in higher education. International Journal of Business and Management, 6(1): 29-44.

Bharadwaj, S. G., Varadarajan, P. R., \& Fahy, J. 1993. Sustainable competitive advantage in service industries: a conceptual model and research propositions. The Journal of Marketing, 57(4): 83-99.

Binsardi, A., \& Ekwulugo, F. 2003. International marketing of British education: research on the students' perception and the UK market penetration. Marketing Intelligence \& Planning, 21(5): 318-327.

Bonnema, J., \& Van der Waldt, D. L. R. (2008). Information and source preferences of a student market in higher education. International journal of educational management, 22(4), 314-327.

British Council. 2018. International student mobility to 2027: Local investment, global outcomes. https://ei.britishcouncil.org/educationintelligence/ei-feature-international-studentmobility-2027-local-investment-global-outcome (accessed 17th July 2019).

Budde-Sung, A. E. 2011. The increasing internationalization of the international business classroom: Cultural and generational considerations. Business Horizons, 54(4): 365-373.

Camilleri, M. A. 2016a. Corporate sustainability and responsibility toward education. Journal of Global Responsibility, 7(1): 56-71.

Camilleri, M. A. 2016b. Reconceiving corporate social responsibility for business and educational outcomes. Cogent Business \& Management, 3(1): 1-14.

Camilleri, M. A., \& Camilleri, A. C. 2017. Digital learning resources and ubiquitous technologies in education. Technology, Knowledge and Learning, 22(1), 65-82. 
Camilleri, M.A., \& Camilleri, A.C. 2019. The Students' Readiness to Engage with Mobile Learning Apps. Interactive Technology and Smart Education. DOI: 10.1108/ITSE-06-2019-0027

Constantinides, E., \& Zinck Stagno, M. C. 2011. Potential of the social media as instruments of higher education marketing: a segmentation study. Journal of marketing for higher education, 21(1): 7-24.

Cronin Jr, J. J., \& Taylor, S. A. 1992. Measuring service quality: a reexamination and extension. Journal of marketing, 56(3):55-68.

De Jager, J., \& Gbadamosi, G. 2010. Specific remedy for specific problem: measuring service quality in South African higher education. Higher education, 60(3): 251-267.

Duque, L. C. 2014. A framework for analysing higher education performance: students' satisfaction, perceived learning outcomes, and dropout intentions. Total Quality Management \& Business Excellence 25(1-2): 1-21.

Estermann, T. 2017. Why university autonomy matters more than ever. University World News, (454), http://www.universityworldnews.com/article.php?story=20170404132356742 (Accessed 28 ${ }^{\text {th }}$ July, 2019).

Estermann, T., Nokkala, T., \& Steinel, M. 2011. University autonomy in Europe II. The Scorecard. Brussels: European University Association. http://agir-ups.info/wpcontent/uploads/2013/01/University_Autonomy_in_Europe_II_-_The_Scorecard.sflb_.pdf (Accessed 28 ${ }^{\text {th }}$ July 2019).

EUA 2017. EUA calls on governments to refrain from interference in university autonomy. http://www.eua.be/activities-services/news/newsitem/2017/04/03/eua-calls-on-governmentsto-refrain-from-interference-in-university-autonomy (Accessed $26^{\text {th }}$ February 2018).

Friga, P.N., Bettis, R.A. \& Sullivan, R.S. 2003. Changes. In graduate management education and new business school strategies for the 21st century. Academy of Management Learning and Education, 2(3): 233-249.

Helms, M. M., \& Nixon, J. 2010. Exploring SWOT analysis-where are we now? A review of academic research from the last decade. Journal of strategy and management, 3(3): 215-251.

Hemsley-Brown, J., \& Oplatka, I. 2006. Universities in a competitive global marketplace: A systematic review of the literature on higher education marketing. International Journal of public sector management, 19(4): 316-338.

Hoecht, A. 2006. Quality assurance in UK higher education: Issues of trust, control, professional autonomy and accountability. Higher Education, 51(4): 541—563.

ICEF 2017. Mapping the trends that will shape international student mobility. http://monitor.icef.com/2017/07/mapping-trends-will-shape-international-student-mobility/ (Accessed 28 ${ }^{\text {th }}$ July, 2019).

Ivy, J. 2008. A new higher education marketing mix: the 7Ps for MBA marketing. International Journal of Educational Management, 22(4): 288-299. 
Kolb, A. Y., \& Kolb, D. A. 2005. Learning styles and learning spaces: Enhancing experiential learning in higher education. Academy of management learning \& education, 4(2): 193-212.

Kotler, P., \& Fox, K. F. 1995. Strategic marketing for educational institutions. New York, USA: Prentice Hall.

Lee, J. T. 2014. Education hubs and talent development: Policy- making and implementation challenges. Higher Education, 68(6): 807-823.

Marginson, S. 2006. Dynamics of national and global competition in higher education. Higher Education, 52(1): 1-39.

Maringe, F., \& Foskett, N. 2002. Marketing University Education: The Southern African Experience. Higher Education Review, 34(3): 35-51.

Maringe, F., \& Gibbs, P. 2008. Marketing Higher Education: Theory and Practice. McGrawHill Education (UK).

Maton, K. 2005. A question of autonomy: Bourdieu's field approach and higher education policy. Journal of education policy, 20(6): 687-704.

Mazzarol, T. 1998. Critical success factors for international education marketing. International Journal of Educational Management, 12(4): 163-175.

Mazzarol, T., \& Soutar, G. N. 2002. "Push-pull" factors influencing international student destination choice. International Journal of Educational Management, 16(2): 82-90.

Mogaji, E. (2016). Marketing strategies of United Kingdom universities during clearing and adjustment. International Journal of Educational Management, 30(4), 493-504.

Moore, M. G., \& Kearsley, G. 2011. Distance education: A systems view of online learning. Belmont, CA, USA: Cengage Learning.

Njenga, J. K., \& Fourie, L. C. H. 2010. The myths about e-learning in higher education. British journal of educational technology, 41(2): 199-212.

Parameswaran, R., \& Glowacka, A. E. 1995. University image: An information processing perspective. Journal of Marketing for Higher Education, 6(2): 41-56.

Pucciarelli, F., \& Kaplan, A. 2016. Competition and strategy in higher education: Managing complexity and uncertainty. Business Horizons, 59(3): 311-320.

Russell, M. 2005. Marketing education: A review of service quality perceptions among international students. International Journal of Contemporary Hospitality Management, 17(1): 65-77.

Schofield, C., Cotton, D., Gresty, K., Kneale, P., \& Winter, J. 2013. Higher education provision in a crowded marketplace. Journal of Higher Education Policy and Management, 35(2): 193-205. 
Van Heerden, N., Wiese, M., North, E., \& Jordaan, Y. 2009. A marketing perspective on choice factors considered by South African first-year students in selecting a higher education institution. Southern African Business Review, 13(1): 39-60. 